\title{
Marine Methane Cycle Simulations for the Period of Early Global Warming
}

\author{
Scott Elliott ${ }^{1}$, Mathew Maltrud ${ }^{1}$, Matthew T. Reagan ${ }^{2}$, \\ George J. Moridis ${ }^{2}$ and Philip J. Cameron-Smith ${ }^{3}$ \\ ${ }^{1}$ COSIM (Climate Ocean Sea Ice Modeling), Los Alamos National Laboratory, Los Alamos, New Mexico \\ ${ }^{2}$ Earth Sciences Division, Lawrence Berkeley National Laboratory, Berkeley, California \\ ${ }^{3}$ Atmosphere Earth and Energy Division, Lawrence Livermore National Laboratory, Livermore, California
}

Corresponding author information:

Scott Elliott

Climate Ocean Sea Ice Modeling

The Computational Sciences Division

Mail Stop D-413

Los Alamos National Laboratory

Los Alamos, NM 87505, USA

(505) 606-0118

sme@lanl.gov 


\section{Abstract}

Geochemical environments, fates and effects are modeled for methane released into seawater by the decomposition of climate-sensitive clathrates. A contemporary global background cycle is first constructed, within the framework of the Parallel Ocean Program. Input from organics in the upper thermocline is related to oxygen levels, and microbial consumption is parameterized from available rate measurements. Seepage into bottom layers is then superimposed, representing typical seabed fluid flow. The resulting $\mathrm{CH}_{4}$ distribution is validated against surface saturation ratios, vertical sections and slope plume studies. Injections of clathrate-derived methane are explored by distributing a small number of point sources around the Arctic continental shelf, where stocks are extensive and susceptible to instability during the first few decades of global warming. Isolated bottom cells are assigned dissolved gas fluxes from porous-media simulation. Given the present bulk removal pattern, methane does not penetrate far from emission sites. Accumulated effects, however, spread to the regional scale following the modeled current system. Both hypoxification and acidification are documented. Sensitivity studies illustrate a potential for material restrictions to broaden the perturbations, since methanotrophic consumers require nutrients and trace metals. When such factors are considered, methane buildup within the Arctic basin is enhanced. However, freshened polar surface waters act as a barrier to atmospheric transfer, diverting products into the deep return flow. Uncertainties in the logic and calculations are enumerated including those inherent in high latitude clathrate abundance, buoyant effluent rise through the column, representation of the general circulation, and bacterial growth kinetics. 


\section{Introduction}

The ocean of today makes only a small contribution to the atmospheric methane budget (Warneck, 2000), but as its floor warms over the next few decades sea-air transfer is expected to increase. Methane clathrates located on the upper continental shelf could dissociate, resulting in trace gas percolation into the bulk water column (Gornitz and Fung, 1994; Reagan and Moridis, 2008). Some of the material will certainly survive transit to the troposphere (Archer, 2007). Activity of this sort should center on the Arctic because shelf areas there are extensive and accessible to the global warming signal (Lamarque, 2008). In fact, clathrates are already emitting from perturbed bottom deposits in some parts of the high latitude north (Archer, 2007; Westbrook et al. 2009). Methane will act as a strong reductant, both in seawater and the photochemical environment of the air (Cicerone and Oremland, 1988; Reeburgh, 2007). Furthermore it will function as a greenhouse gas, with a time-dependent effectiveness dozens of times as great as $\mathrm{CO}_{2}$ (IPCC, 2007). In the present work a first attempt is made to assess the fate of clathratederived methane by simulating pathways by which the molecule will influence, and also in turn be controlled by, marine geochemistry as it makes its way from sediments through overlying seawater.

A background methane cycle is incorporated first, within a version of the global Parallel Ocean Program specifically augmented for ecodynamic and dissolved trace gas computations (biogeochemical POP -Moore et al. 2004; Elliott, 2009). Natural injection rates are based on community knowledge of the internal microbial and seabed fluid flow sources (Judd, 2003; Reeburgh, 2007). Observations of removal from seawater are 
analyzed to parameterize the highly variable methane residence time (de Angelis et al. 1993; Rehder et al. 1999; Valentine et al. 2001). The ocean surface is confirmed to comprise a negligible but net-positive component of the current atmospheric geocycle.

With a contemporary marine budget established, continental slope clathrate emissions are added to POP methane processing for selected destabilization sites. Fluxes are derived from recent 1-D modeling of clathrate decomposition under global change (Reagan and Moridis, 2008). Shallow Arctic deposits along the polar shelf break and in peripheral northern seas are the focus (Gornitz and Fung, 1994; Cranston et al. 1994; Archer, 2007; Westbrook et al. 2009). Simulated methane inputs are confined to selected bottom cells one degree on a side, to capture geochemical behaviors during the onset of clathrate destabilization. Stoichiometry is then tracked for the oxidation reaction forming $\mathrm{CO}_{2}$.

Next a series of sensitivity runs is brought to bear, aiming at issues of resource availability and the efficiency of consumer methanotrophs (de Angelis et al. 1993; Reeburgh, 2007). Familiar metabolic restrictions for nonphotosynthetic bacteria apply (oxidants and nutrients), along with specialist trace metal needs dictated by the $\mathrm{CH}_{4}$ bond strength (King, 1992; Hanson and Hanson, 1996). Requirements for processing the dissolved gas are compared with high latitude ocean water composition (HAAO, 2001; WOA, 2005). In addition to dissolved oxygen, nitrate and certain transition elements are considered as potential limiting reagents using Monod switch criteria to mimic nutrient undersaturation (Christian and Anderson, 2002). Methane from the patch emissions is then segregated for treatment as an inert tracer, to gauge the maximum plume spread. 
Uncertainties are discussed relative to all aspects of the simulations. The heterogeneous and enigmatic nature of clathrate distributions is reviewed (Milkov, 2004; Archer, 2007). Inconsistencies in the model general circulation are listed, with emphasis placed upon the polar halocline barrier to vertical transport (Schlosser et al. 1995; Holloway et al. 2007). Special attention is paid to details of the methane oxidation ecology, which the authors feel will soon demand treatment of both its population and resource dynamics.

\section{Models and Methods}

2.1 Ocean Model. The methane cycle simulations developed here take as their framework a one degree resolution, global Parallel Ocean Program configuration with 40 vertical levels. The code is essentially a stand-alone version of the Community Climate System Model (CCSM) ocean, Release 3 (Gent et al. 2006). It is enhanced with the ecodynamics and biogeochemistry packages described by Moore et al. (2004), and also with subroutines necessary for the simulation of dissolved trace gas chemistry-transport. Physical and biological settings are identical with those described in the recent global dimethyl sulfide studies of Elliott (2009). They will be summarized only briefly here.

Horizontal tracer diffusion is handled through the formulation of Gent and McWilliams (herein GM; 1990), and horizontal momentum diffusion using the anisotropic viscosity developed by Smith and McWilliams (2003). Vertical diffusion coefficients are calculated using the K- Profile Parameterization (KPP -Large et al. 1994). All tracers are advected by applying a flux limited Lax-Wendroff scheme, which is monotone and 
essentially positive definite. The simulation time step is approximately one half hour. Momentum, heat and fresh water fluxes are calculated from the 6-hourly Normal Year of the CORE1 ocean model forcing dataset. This is meant to provide a robust, repeatable annual cycle of atmospheric fields based on recent observations and reanalysis (Kalnay et al. 1996; Large and Yeager, 2004). Surface temperature and salinity are restored with a time constant of 30 days, to monthly climatological values beneath a specified sea ice coverage. To avoid drift, surface salinity is restored across the ocean on a one year scale.

2.2 Methane Processing. The euphotic zone ecodynamics mechanism adopted is that of Moore et al. (2004), incorporating multiple phyto- and zooplanktonic bins plus detritus for all the elemental currencies required in carbon cycle simulation (N, P, Si, Fe). Mesozooplankton, sinking particulate organics and dissolved $\mathrm{O}_{2}$ are among the tracers, and all play into upper ocean methane release (Oremland, 1979; Cicerone and Oremland, 1988; Tilbrook and Karl, 1995). Most of the runs conducted here, however, link production solely to a decrement in $\mathrm{O}_{2}$. The subsequent cycling is simulated in a module specifically designed for handling trace gas distributions (Elliott, 2009). This is separated computationally from the major element ecodynamics but can feed back through $\mathrm{O}_{2}$ consumption and the generation of carbonate, as in $\mathrm{CH}_{4}+2 \mathrm{O}_{2} \rightarrow \mathrm{CO}_{2}+2 \mathrm{H}_{2} \mathrm{O}$ (Hanson and Hanson, 1996). In a small subset of runs, uptake of nitrogen compounds is considered as well $\left(\mathrm{NO}_{3}{ }^{-}, \mathrm{NH}_{4}{ }^{+}\right)$.

The natural ocean methane cycle is adopted as a starting point, both to form a backdrop for seafloor clathrate injections and also to provide confidence in production, transport 
and removal parameterizations. The contemporary distribution has previously been modeled conceptually and in the vertical dimension relative to the open water column (Scranton and Brewer, 1978; Nihous and Masutani, 2006; Reeburgh, 2007). Lack of interest in developing a global simulation capability can be attributed to the small contribution of surface exchange in tropospheric budgets (Bange et al. 1994; Bates et al. 1996). Even a strong excursion from familiar supersaturations would not play into the atmospheric greenhouse. However, it is also the case that data sets are hard to come by.

Throughout the upper ocean methane inputs follow from an organic chemical decomposition system, fueled from above by pelagic ecosystems. Both particulate and dissolved organic matter make their way into the thermocline and are operated on by local microbial communities. As the more abundant terminal electron acceptors are depleted, $\mathrm{CH}_{4}$ becomes an energetically viable disproportionation or demethylation product (Stumm and Morgan, 1981; Reeburgh, 2007). Since seawater is an oxidizing medium and methanogens require stringent anoxia, it has been widely assumed for several decades that production must take place within physically isolated microzones. The guts of higher trophic level consumers, their fecal pellets and generalized sinking particles have all been considered candidate locations (Oremland, 1979; Tilbrook and Karl, 1995). More recently, reactions have been proposed which lead abiotically from ambient organophosphorous compounds (Karl et al. 2008). These newer pathways will not be considered. 
By analogy with all other biogeochemical tracers, the evolution of methane concentration is modeled as advection-diffusion supplemented with local sources and sinks.

$$
\frac{\left.a \mathrm{CH}_{4}\right]}{a}+\mathbf{u} \cdot \nabla\left[\mathrm{CH}_{4}\right]=\text { Source }- \text { Removal }+ \text { Diffusion }
$$

where $\mathbf{u}$ is the ocean velocity, and Diffusion is calculated by GM and KPP. Injection into the water column is computed in proportion to the decrement of dissolved $\mathrm{O}_{2}$ relative to well-ventilated maxima,

$$
\begin{aligned}
& \text { Source }=\mathrm{S}_{0}\left[\mathrm{O}_{2}{ }^{\text {max }}-\mathrm{O}_{2}\right] / \mathrm{O}_{2}{ }^{\text {max }} \text { for } \mathrm{O}_{2}<\mathrm{O}_{2}{ }^{\text {max }} \\
& \text { Source }=0 \text { for } \mathrm{O}_{2}>=\mathrm{O}_{2}{ }^{\text {max }}
\end{aligned}
$$

where $\mathrm{S}_{0}=10^{-5} \mu \mathrm{M} /$ day. The latter equation set was determined through sensitivity tests, and also by comparison with previous estimates based on 1-D budget exercises and particle trap experiments (Reeburgh, 2007). Since 2 is meant to represent upper ocean production, it is zeroed below 250 meters. Overall this approach acknowledges that falling particles may be involved both because they provide carbon atoms and also a sink for oxidants. A more realistic portrayal of remote methanogenesis might be achieved by fractionating the remineralization stream for organic particles. Given our emphasis on clathrates, however, such refinements were judged unwarranted.

Removal rates of methane from deep seawater have been measured by several methods including addition of isotopically labeled substrate, recruitment of inert tracers of opportunity, and evaluation of the reaction versus transport competition (de Angelis et al. 1993; Rehder et al. 1999; Valentine et al. 2001). A summary of the available data is provided in Table 1. The tendency exists for rate determinations to cluster around known hydrocarbon sources and to lie near major centers of oceanographic activity (Reeburgh, 
2007). Under such circumstances, the data can hardly be considered representative.

Although the spread is large for any one concentration, typical time constants can be fit reasonably well by an empirical, log linear relation. At steady state the local value may then be estimated as a quadratic. We model lifetime and removal as

$$
\begin{aligned}
& \log _{10} \tau=1-\log _{10}\left[\mathrm{CH}_{4}\right] \\
& \text { Removal }=\mathrm{CH}_{4} / \tau=0.1\left[\mathrm{CH}_{4}\right]^{2}
\end{aligned}
$$

In these expressions, $\tau$ has units of days and methane is in $\mu \mathrm{M}$. Reasons for an apparent scaling of the removal time have not been analyzed extensively in the literature. Early speculation centered on Monod type limitations imposed by low concentrations of unspecified nutrients in the abyss, or by the methane molecule itself (Scranton and Brewer, 1978; Christian and Anderson, 2002). Several authors have noted that deep source waters or the sediment vicinity seem to provide seed organisms which then bloom into the plume (de Angelis et al. 1993; Grant and Whiticar, 2002). Since e-folding will essentially be determined by maximal bacterial growth rates as consumers begin to deplete the supply (as biomass approaches that of the substrate; de Angelis et al. 1993), it may be hypothesized that some combination of Monod, seeding and kinetic catch-up factors explain the observed variation. Strong sources may well be associated with sediment ecosystems or local shelf biota, which are effectively primed for consumption. This notion remains to be tested but will motivate much of our simulation activity.

Methane is also interchanged between ocean and atmosphere at the surface interface, using the molecule-specific transfer coefficient of Wanninkhof (1992) and seawater solubility data from Wiesenburg and Guinasso (1979). Following Bates et al. (1996), a 
(constant) global average gas phase mixing ratio of $1.75 \mathrm{ppm}$ is adopted. The value is representative of the atmospheric state near the turn of the recent century (Warneck, 2000). Uncertainties in the quantities relevant to atmospheric flux are of order $10 \%$, but they should nonetheless constitute the best grounded components of the entire loss scheme since the biota are not directly involved.

2.3 Contemporary Sediment Inputs. Natural fluxes of methane from the seafloor are poorly characterized but appear to be associated mainly with the continental margins, by virtue of their hydrocarbon accumulation history and tectonic activity (Judd, 2003). The total input has been estimated at $20 \mathrm{Tg} / \mathrm{yr}$ (Judd, 2003) but is uncertain by at least an order of magnitude (see e.g. Hovland et al. 1993 and Kvenvolden et al. 2001). Since the diverse geological features involved vary in scale/intensity from seeps to mud volcanoes and are heterogeneously distributed, the expedient is adopted here of distributing an estimated global source strength evenly, over the entire ocean bottom between the depth contours 100 and 1000 meters. Although there are well established cases of shallow seepage and extreme methane supersaturation in water only a few meters deep (Bange et al. 1994; Mau et al. 2007), such instances are relatively rare. Spread over the above shelf/slope extent, the Judd budget gives an average flux of $3 \times 10^{-9} \mathrm{~mole} / \mathrm{m}^{2} \mathrm{~s}$. Related estimates span a factor of three on either side. Sensitivity studies revealed that a value one order of magnitude below the central figure provided best agreement with coastal plume data (e.g. de Angelis et al. 1993; Ward and Kilpatrick, 1993; Lammers et al. 1995a; Suess et al. 1998; Grant and Whiticar, 2002). This may indicate either that 
budgets for the seafloor source have been overestimated, or that the log linear lifetime approach is oversimplified.

2.4 Clathrate-Derived Methane. The Arctic Ocean harbors a high proportion of the global methane hydrate reservoir because it is cold and relatively shallow (Archer, 2007). Regional expanses of sediment containing clathrates are likely to warm quickly under climate change due to their close communication with mid-latitude source waters (IPCC, 2007; Westbrook et al. 2009). The subsurface North Atlantic Layer is of particular interest here because it tends to hug the shelf break between 200 to 500 meters depth (Schlosser et al. 1995), near the top of the present day clathrate stability zone. Since this water mass is in bottom contact, the increase in its temperature will be experienced rapidly by any shallow deposits (Reagan and Moridis, 2008). It is clear that hundreds of thousands of square kilometers of Arctic bathymetry may cross outside of the stability zone as warming unfolds (Lamarque, 2008).

Reagan and Moridis (2008) performed the first fully coupled flow, transport and decomposition simulations for marine clathrates subjected to ocean warming, in a 1-D model of porous flow through the sediment column. Their cold, shallow case at 320 meters is Arctic-specific. Total methane fluxes are of order $10^{-6} \mathrm{~mole} / \mathrm{m}^{2} \mathrm{~s}$ when fast seafloor temperature rise is coupled to moderate pore saturations (above 3\%). Note that such rates are orders of magnitude higher than the natural background derived above. New high latitude emissions may thus constitute an unprecedented pulse from the seabed. Since the goal here is to estimate an extreme potential response, $10^{-6}$ was chosen as the 
value for a superimposed, clathrate-driven input. The empirical logarithmic time constant for methane removal is retained in the decomposition runs initially. High concentrations resulting from the additional emissions will be removed quickly, so that the steady state with equation 5 becomes an even more useful guide.

We selected 8 individual Arctic grid cells on the 300 meter depth contour and applied such methane injections to represent localized clathrate dissociation (Figure 1). The choice of locations was based on the extent of shelf at the appropriate level, plus its likelihood of containing clathrate. Probability of hydrate buildup was assessed roughly under the criteria defined by Gornitz and Fung (1994), involving the conjunction of biological and thermogenic methane sources. In some cases the emission cells are positioned beneath productive surface waters (Longhurst, 1998), and in other instances near known bottom-simulating reflectors, pock fields, or seeps (e.g. Kvenvolden and Grantz, 1990; Cranston et al. 1994; Lammers et al. 1995a and b). All are consistent with state-of-the-art hydrate budget reviews and mapping procedures (Milkov, 2004).

2.5 Simulation Design. The model general circulation was started from rest under January temperature and salinity distributions of the Polar Science Center hydrographic climatology (Steele et al. 2001). After 50 years, currents of the upper ocean were judged to be in quasi-equilibrium. Following preliminary spin-up of the physics, nonmethane ecology and the elemental geocycling were introduced with a combination of WOA (2005), GLODAP (Sabine et al. 2005) and idealized initial conditions. After 30 further 
simulation years, the open ocean regime entered a modern biotic steady state as

evidenced by comparison with data sets including satellite chlorophyll (e.g. WOA, 2005).

At this point methane concentrations were initialized everywhere to $1 \mathrm{nM}$, a level just below atmospheric saturation and most open ocean measurements. For the first 30 years of methane computation, seafloor flux was disabled to focus on the remote column. A steady-state partial distribution was obtained for the top several hundred meters. Upward flow from the bed was then switched on and the simulation continued for another 10 years. Concentrations in the true abyss were still falling at this stage, because equations 4 and 5 imply a finite lifetime even at extreme low levels. Unfortunately only a handful of deep ocean rate determinations can be called upon for validation or guidance (e.g. Scranton and Brewer, 1978; Rehder et al. 1999). All of them are highly uncertain, but stability is indicated almost to the century scale. The drift is thus an artifact, but it remained sufficiently slow that it could be ignored. On completion of a methane background, the 8 injections of Figure 1 were activated. All simulations involving clathrate dissolution begin from this same initial state and continue for 30 years.

\section{Results}

3.1 Background Methane Cycle. A selection of results for the natural methane cycle is presented in Figure 2, and the agreement with measurements may be assessed based on Table 2. The pattern in surface fields is one of Henry's Law near-equilibration relative to current atmospheric chemistry (Bates et al. 1996; Warneck, 2000), but allowing for coastal supersaturation. The temperature dependence of solubility leads to an increase of 
several $\mathrm{nM}$ moving from the tropics toward the poles, with peaks of order $10 \mathrm{nM}$ over broad shelf areas. In Arctic waters maxima span extensive shelf regions of the Barents Sea, Canadian Archipelago and Greenland coast, which for the most part lie outside zones of long-term ice cover. The prediction of synoptic polar highs may not be unrealistic. For example, plume studies over Barents pock fields yield double-digit values within the mixed layer (Lammers et al. 1995a). Coastal surface measurements near accessible seeps range from hundreds of nM up to $1 \mu \mathrm{M}$ (Rehder et al. 2002a; Mau et al. 2007). In the Antarctic, maxima are centered under zones of permanent sea ice coverage since gas exchange is prevented.

Along a few meridional ship tracks over the Pacific and Atlantic basins, methane supersaturation has been measured extensively (Conrad and Seiler, 1988; Bates et al. 1996). Values are of order $1 \%-10 \%$ in the central gyres and $10 \%+$ along equatorial divergences. This combination closely matches the model distribution in Figure $2 \mathrm{~b}$. Undersaturation can occur in areas of ice cover since sources may shut down while removal continues. The effect can persist as ice retreats in summer. Beneath cold ventilated layers the equation 2,3 set minimizes internal production, and saturation ratio provides an indicator. The effect may be real—it is suggested in Southern Ocean transects (Bates et al. 1996). The global saturation distribution agrees with all measurement data employed to perform flux integrations or atmospheric budgeting (e.g. Bange et al. 1994; Bates et al. 1996). Globally integrated emissions in our simulations are $0.5 \mathrm{Tg} \mathrm{CH} / \mathrm{yr}$, consistent with the estimate of Bates et al. (1996). Our background cycle thus requires no adjustment to the conventional wisdom that flow from the ocean is 
small. Bange et al. (1994) concluded that about three quarters of total sea-air transfer is concentrated within one quarter of the ocean surface. The model is in accord and verifies that the areas in question are mainly coastal.

The concentration distribution is shown just below the mixed layer in 2c, with contours of dissolved $\mathrm{O}_{2}$ superimposed. Since production is proportional to an oxygen deficit, tongues penetrating into the central basins follow contours of hypoxification, which are generated during remineralization of sinking organics (Moore et al. 2004). Methane values reach 10-20 nM inside of the most intense $\mathrm{O}_{2}$ minima. In ventilated areas by contrast, they remain near surface saturation as expected. All of these features are in common with the few depth sections that have been reported (Conrad and Seiler, 1988; Tilbrook and Karl, 1995; Watanabe et al. 1995; Kelley and Jeffrey, 2002).

3.2 Clathrate Injections. Hydrate decompositions were introduced simultaneously at all of the 8 Arctic locations, beginning after the 40 year methane background simulation. The enhancements are displayed as depth integrals in Figure 3a. The injection points are clearly visible, but two hot spots in the image should be noted and set aside immediately as false positives. Just poleward relative to the Denmark and Davis Straits, sills form small bathymetric depressions in which mixing is reduced and the average fluid flow accumulates. The selected color scale accents these features, but they are natural maxima.

The hydrate destabilizations produce peaks greater than 100 millimole $/ \mathrm{m}^{2}$, corresponding to $\mu \mathrm{M}$ over a 100 meter scale length in more direct contact with the shelf. The local 
steady state approximation is several $\mu \mathrm{M}$, and near-field dilution accounts for the difference. Due to a combination of high removal rates and weak bottom currents, the additional methane does not travel far from the points of release. Figure 3b indicates that it is also true in the vertical dimension -most of the compound is oxidized prior to transport. However, this does not mean that influence is strictly local. The dispersing material is lost primarily through microbial oxidation. Consumption of metabolic reagents and subsequent product buildup imply effects over a broad area. To account for the connections, we incorporated the stoichiometry $\mathrm{CH}_{4}: \mathrm{O}_{2}$ :carbonate $-1:-2:+1$ (Cicerone and Oremland, 1988; Hanson and Hanson, 1996). The process alters $\mathrm{O}_{2}$ and the Dissolved Inorganic Carbon field (DIC) within the ecosystem code.

Across the Arctic basin proper, dissolved $\mathrm{O}_{2}$ is maintained near Henry’s Law equilibrium with the gas phase through recent communication with the atmosphere. The peripheral Okhotsk and Bering Seas, on the other hand, are highly productive at the surface but poorly ventilated at depth (Longhurst, 1998). Gas depletion characterizes their intermediate water masses (Cranston et al. 1994; Freeland et al. 1998; WOA, 2005). Natural concentrations of $\mathrm{O}_{2}$ fall to tens of $\mu \mathrm{M}$ over large volumes. In these two areas, methane oxidation is sufficiently intense to accentuate hypoxia in our model runs. Concentrations are pulled to near zero on the western sides of both basins, as shown in Figure 4a. Detrimental effects of hypoxia on advanced organisms have their onset between 1 and $10 \mu \mathrm{M}$ (Brewer and Peltzer, 2009). Microbial methane cycling may thus dictate both redox properties and biological viability of the boreal water column in marginal basins. Similar effects are associated with the shelf break in the figure, but they 
are barely discernible relative to the normal aeration level. Additions of carbonate due to the oxidation cause acidification as DIC approaches local alkalinity (Broecker and Peng, 1982; Peng et al. 1987). The effect is strongest in sluggish water masses, but peak heights in the East Siberian and Beaufort seas are comparable (Figure 4b).

3.3 Limitation and Sensitivity. In order to directly impact the global greenhouse, methane emanating from sedimentary hydrate must run the gauntlet of marine biology above the shelf zone. For atmospheric budgeting purposes the assumption is often made that removal will necessarily be rapid and complete. In estimating clathrate sources during the next century, for example, Lamarque (2008) has recently applied the loss rate from a single Santa Barbara channel study (Mau et al. 2007) to all of future planetary scale destabilization. An underlying rational here is that lifetime patterns shown in Table 1 will remain unchanged. But upcoming methane injections confronting the Earth System will ultimately be unprecedented in mass and scope. Fluxes from the ocean bottom may well dwarf those of contemporary systems investigated thus far. From the calculations already presented, it is clear that effects may permeate much of the Arctic basin. Consumers will be forced to deal with a host of nutritional and kinetic challenges in order to remove the molecule before it reaches the sea surface, and they will have to do so in uncharted portions of the geochemical parameter space. In the present section an attempt is made to begin sorting out major relationships and consequences.

It is believed that organisms most often responsible for methane oxidation in the global ocean are the group of bacteria known as methanotrophs (Bedard and Knowles, 1989; 
King, 1992; Hanson and Hanson, 1996). The class is physiologically and metabolically quite diverse, but it may be divided into two major types. One requires copper as a trace metal cofactor in its methane monooxygenase enzyme system (MMO), while the other relies on iron (Hanson and Hanson, 1996). Species emphasizing the copper pathway utilize nitrate as a nutrient, while iron is linked to nitrogen fixation capabilities that manifest themselves under conditions of reduced $\mathrm{O}_{2}$ - the cells can become diazotrophic under stress. Ammonia is always present in upper layers because it remineralizes from the photosynthate, and it can fertilize any of the oxidizers. Across the global aqueous environment, the most general observation regarding methanotrophs is that the two varieties will coexist as seed populations whenever methane and $\mathrm{O}_{2}$ intermix. Under changing conditions, they compete with one another based on in situ copper $/$ nitrate $/ \mathrm{O}_{2}$ levels. Clathrate destabilization is therefore likely to create vast new volumes of habitat, but these will be characterized by strong taxonomic and geochemical gradients.

Sensitivity to resource availability was explored in POP by implementing simple threshold criteria that turn off microbial consumption if key elements are not present in sufficient quantity. Simulations were again conducted working from background fields, then continuing a further 30 years with clathrate injection. Limitation by methane itself is of course possible (Scranton and Brewer, 1978; Hanson and Hanson, 1996), but several authors have noted that the half-saturation constant is plastic, surprisingly low and difficult to determine in culture (King, 1992; Conrad, 1994). Undersaturation is in any case embodied conceptually through the empirical lifetime. The basic metabolic reaction $\mathrm{CH}_{4}+2 \mathrm{O}_{2}$ was shut down if oxygen concentrations dropped below $10 \mu \mathrm{M}$, since this 
appears to be about the level at which methanotrophs lose viability (Schubert et al. 2006; Blumenberg et al. 2007). In the Arctic Basin itself, ambient gas levels are high enough that processing is never curtailed. Results are essentially identical to the baseline release. However with the $\mathrm{O}_{2}$ threshold in force, methane plumes in the Okhotsk and Bering expand considerably (Figure 5). Decay only sets in following the admixture of surrounding, partially oxygenated waters.

Trace metals functioning as cofactors in the MMO enzyme are present in high latitude seawater only at concentrations of pico- to nanomolar (Heggie et al. 1987; Aguilar Islas et al. 2007). Such levels may lie below the elemental saturation constants for growth (King, 1992; Graham et al. 1993; Berson and Lidstrom, 1996; Hanson and Hanson, 1996), or alternatively could prove to be mass limiting in themselves. Iron is a wellknown phytoplanktonic nutrient and so it is carried by the standard POP ecology. Copper, however, does not fall in this category and so it is not currently simulated. The two should interact strongly in the determination of consumer taxonomic distributions. Since copper chemistry would demand substantial model reconfiguration, inert tracer experiments were conducted to bracket any trace metal effects. A second methane tracer was added to the model suite representing stabilized dispersal, which creates an upper bound on plume spread. This inert component is identical to the original, except that it is devoid of reaction (infinite $\tau$ ). Under these circumstances methane plumes extend even further, filling the entire Arctic basin (Figure 6a). Oceanographic export actually begins to move tracer mass into the North Atlantic, through Denmark and Davis Straits. In vertical profile, the effluent remains within \pm 200 meters of the injection depth (6b). 
Transport through ocean surface water poses a final barrier to atmospheric access, and Arctic hydrography is distinct in this regard (Schlosser et al. 1995). The mixed and adjoining layers are freshened by intense circumpolar riverine input. The main pycnocline is more accurately termed a halocline, since it is descendent from the Gulf Stream and relatively warm. To begin quantifying and analyzing vertical transfer processes, we integrated ocean-atmosphere interfacial fluxes for the inert tracer run. Ratios against total patch emissions were then computed. The values obtained are low, asymptoting at about 1\% (Figure 7). Thus even if microbiology fails to intercept the effluent, dissolved methane gas may encounter a hard fluid-dynamic ceiling. Within the landlocked ocean proper, aggregate plumes simply perform a circuit of the shelf break and finally are subsumed into the global meridional overturning. Model physical structures act as a methane filter above and beyond any biogeochemical reaction scheme.

A flow tube model of the system is instructive here, with atmospheric loss viewed as a branching pathway. Based on in situ tracer studies, the time constant for cyclonic flow around the shelf break in the Arctic is about 30 years (Schlosser et al. 1995). Transfer from open surface layers to the gas phase is immediate on this scale. Only a few years are needed to move material from beneath the permanent pack into seasonally covered coastal zones. Moreover, there may soon be no multiyear ice to contend with at all. Halocline diffusion must be the rate-determining step in communication with the troposphere. In the present POP configuration, an average scalar diffusivity of order tenths $\mathrm{cm}^{2} / \mathrm{s}$ is assigned to vertical mixing in shallow layers (Large et al. 1994). Upward 
movement is therefore slow relative to the shelf circuit. This clearly constitutes a negligible channel in the Figure 6(7) run. Simulated polar currents route clathrate outflow efficiently back into the deep Atlantic where even dilute removal times are likely adequate (Rehder et al. 1999). We will not explore the potential for remixing via strong convection in the Greenland and Iceland seas.

Uptake of various nitrogen forms was introduced into the model biogeochemistry in a final set of sensitivity runs. Both nitrate and ammonia operate dynamically in the bulk ecology module, so that connections could be made directly. The influence of $\mathrm{NO}_{3}{ }^{-}$was minimal due to its relative abundance. Concentrations are typically in the $10 \mu \mathrm{M}$ range (HAAO, 2001; WOA, 2005), and the selected patch distribution did not yield significant depletions. Accordingly, results are not presented. Ammonia limitation was also investigated in a few simulations, but under an excess of nitrate there may well be little need for the methanotrophs to call upon reduced compounds. In fact within the bimodal methanotrophic class system, it appears that even oxidized nitrogen may be nonessential. Diazotrophic type II consumers have the ability to fix molecular $\mathrm{N}_{2}$ and so create a virtually limitless pool of nitrogen atoms ad lib (Hanson and Hanson, 1996). If nitrate restrictions are to make themselves felt, there are three preferred situations; 1) toward the remote Arctic basin center, ice algal production leads to nutrient drawdown and a zone of upper level depletion to $1 \mu \mathrm{M}$ or less, 2) in the Mackenzie delta and Canadian Archipelago, Atlantic mode nutrient concentrations are experienced (Walsh et al. 2004), and 3) high photosynthetic activity fueled by winter/spring convection can fully extract oxidized N at lower latitudes (Longhurst, 1998). 


\section{Summary and Discussion}

The global marine methane cycle and upcoming polar clathrate releases have been simulated in a one degree version of the biogeochemical Parallel Ocean Program. Background distributions in the model are determined by just two main source types methanogenesis within sinking particles and upward fluid flow from the sea bed (Judd, 2003; Reeburgh, 2007). The first component of production is set proportional to the $\mathrm{O}_{2}$ decrement at a few hundred meters depth (equations 2 and 3). Budgets for the fluid injection pathway were averaged onto the global slope to reproduce effects of seepage and mud volcanoes. Removal is represented by a log linear function which captures scaling of the methane lifetime against its own concentration (equations 4 and 5 plus Table 1). Contemporary open water distributions consist of near Henry’s Law equilibrium at the surface, supplemented below biologically active areas by a broad 10 nanomolar peak in the thermocline. Slow decay into the abyss follows. The central layer maintains slight supersaturations at the atmospheric interface due to vertical mixing. In coastal areas over broad stretches of continental slope, tens of nanomolar are predicted and may reach well above the seafloor. Measurement data remain sparse but suggest that major patterns in the background simulation are realistic (Table 2 and Figure 2).

The vast Arctic shelf supports massive hydrate reservoirs, and many are close to the edge of stability (Archer, 2007). Since these deposits are often located in the depth range of recently ventilated North Atlantic water masses, relatively small increases in temperature due to climate change may result in dissociation (Lamarque, 2008). In the present study, 
methane flow from warming clathrates is calculated by porous-media simulation (Reagan and Moridis, 2008). The gas is then locally injected into the POP water column at selected sea bottom locations distributed around the Arctic and northern high latitudes. In a baseline run methane plumes do not extend far beyond the release sites, due to the logarithmic removal rate (Figure 3). Product accumulation, by contrast, is sufficient to alter dissolved inorganic carbon concentrations relative to alkalinity, resulting in regional acidification in the range $0.1-0.2 \mathrm{pH}$ units. Moreover, thresholds for the detrimental biotic effects of hypoxia can readily be crossed (Brewer and Peltzer, 2009). Oxygen losses are most dramatic in regions of ambient undersaturation such as the Okhotsk Sea (Figure 4).

Organisms performing the Arctic methane removal will likely be types I and II methanotrophs (de Angelis et al. 1993; Hanson and Hanson, 1996). Their collective metabolism is subject to specialized supply and demand considerations such that macroor micro-nutrient limitation could affect catabolism/growth. The transition metals iron and copper function as cofactors in the critical monooxygenase enzyme, and so may determine methane dispersion in part. Over a series of sensitivity runs, relevant nutritional constraints were introduced by imposing shutdown thresholds on the net oxidation reaction. Dissolved $\mathrm{O}_{2}$ limitation extends the volume of methane plumes to the synoptic scale (Figure 5), while nitrate is usually available in excess at the selected injection sites. In order to consider more complete limitation, a second methane-like tracer was added to the model for which all internal reaction rates were zeroed. In this case, the entire Arctic basin fills in a few decades (Figure 6). Impermeable, freshened 
surface layers guide all but approximately $1 \%$ of the clathrate product toward storage and removal in the subpolar deep sea (Figure 7).

Many simplifying assumptions underlie this calculation sequence and demand further investigation. The manner of methane injection from sediments may constitute the most important example. Details of buoyant emissions rise have been subsumed entirely here. The slight desalination imparted by clathrate dissociation can most likely be neglected (Coffin et al. 2006; Reagan and Moridis, 2008). In the absence of organic or solid coatings, populations of small bubbles must be dense to survive more than ten meters of upward movement (Leifer et al. 2000; Leifer and Patro, 2002; Rehder et al. 2002b; Heeschen et al. 2003). The grid thickness at our reference depth is several times greater, so that full dissolution would seem an acceptable starting point. At the newly discovered Spitsbergen site, however, bubble heights exceed 100 meters (Westbrook et al. 2009). Other recent work suggests wide-area sources may exhibit enhanced vertical transport (Leifer et al. 2009). Implied uncertainties approach the halocline dimension (Schlosser et al. 1995), so that the surface layer ceiling could be partially bypassed. Mixing within the water column is itself poorly understood, and is exceptionally intricate around the polar shelf. Fine features such as brine rivers and topographically steered canyon flows are present in abundance (Schlosser et al. 1995). Physical behaviors near the halocline are not yet captured consistently by general circulation models (Holloway et al. 2007), and the effects of internal tides are not included. 
Hydrate effluent will not in fact emerge as the neat horizontal average depicted by porous flow computations. In reality it will be heterogeneous, with local inputs exceeding the Reagan and Moridis (2008) maxima coexisting in close proximity with values approaching zero. Flow along subinterfacial strata is possible, and venting can then take place far afield (Egorov et al. 1999; Damm and Budeus, 2003). Per review material presented by Gornitz and Fung (1994) and Archer (2007), the continental shelf itself may constitute a critical inhomogeneity. Slumping, collapse and cascade decompositions have all been documented across large sections. Deconstruction of the sediment matrix may lead to solid clathrate entering the water column. The pieces would rise rapidly toward the surface (Brewer et al. 2002) and dissociate upon leaving the stability zone. The kinetics of dissolution will be challenging, and a strong analogy exists with bubble rise.

Another simplification has been our use of contemporary physical forcings at the ocean surface, to drive circulation of methane that will not enter the water column for several decades to come. Encroachment of the global warming signal should be gradual in central layers (IPCC, 2007; Lamarque, 2008). We consider it unlikely that Arctic currents will change enough in the near term to substantially alter hydrate plume directions. On the other hand, the extent of Arctic sea ice is already decreasing demonstrably. Coverage by the polar pack blocks sea-air transition of trace gases very effectively (Schlosser et al. 1995; Lammers et al. 1995b). Loss of multiyear buildup will reduce resistance over the atmospheric pathway, further complicating our halocline penetration logic. 
When- and wherever Arctic surface layers cannot prevent atmospheric transfer, the biosphere constitutes a last line of defense. But uncertainties are pervasive in this realm as well. Empirical decay equations clearly cannot hold at arbitrarily high methane concentrations. Even for intermediate situations they must be viewed as a crude approximation. In fact conversion times will scatter widely around our zeroth-order relation, depending on local conditions. Removal will play out not just as a function of concentration patterns, but based on the full diversity of marine biogeochemistry. True plume dynamics will involve bacterial seeding and Monod-style, multilevel resource limitations (Hanson and Hanson, 1996; Christian and Anderson, 2002). The methanotrophs are probably ubiquitously distributed through the sea, and growth rates do not slow in cold or pressurized systems (de Angelis et al. 1993; LaRock et al. 1994). The substrate will itself be present in excess in any massive decomposition plume. We have therefore speculated that alternative metabolic switches may exist $\left(\mathrm{O}_{2}\right.$, metals etc.). But in next-generation models it will be necessary to treat the consumers prognostically, by invoking realistic competitions.

Renewed laboratory work will of course supply some of the requisite parameters for this effort. Field campaigns, which must be conducted in parallel, will be forced to enter at a new plane. Even the strongest contemporary seabed injection features such as mud volcanoes do not generate plumes of the magnitude indicated by climate change simulation (Damm and Budeus, 2003 vs. Lamarque, 2008). Furthermore, the geography of clathrate dissociation will remain enigmatic into the foreseeable future (Milkov, 2004; Westbrook, 2009). It would thus seem that emissions of opportunity must be targeted for 
biological study, and further, that intentional or engineered releases should be considered as well.

Acknowledgements. The authors have been supported by the U.S. Department of Energy (DOE) Assistant Secretary for Fossil Energy, Office of Natural Gas and Petroleum Technology, and also by the DOE Office of Science Biological and Environmental Research IMPACTS project for Abrupt Climate Change. Partial support was also provided by DOE and LBNL under Contract Number DE-AC02-05CH11231.

\section{References}

Aguilar-Islas, A.M., and 6 others, Micro- and macronutrients in the southeastern Bering Sea; Insight into iron depleted regimes, Prog. Oceanogr. 73, 99-126, 2007.

Archer, D., Methane hydrate stability and anthropogenic climate change, Biogeosciences 4, 521-544, 2007.

Bange, H.W., U.H. Bartell, S. Rapsomanikis and M.O. Andreae, Methane in the Baltic and North Seas and a reassessment of the marine emissions of methane, Global Biogeochem. Cycles 8, 465-480, 1994.

Bates, T.S., K.C. Kelly, J.E. Johnson and R.H. Gammon, A reevaluation of the open ocean source of methane to the atmosphere, J. Geophys. Res. 101, 6953-6961, 1996.

Bedard, C., and R. Knowles, Physiology, biochemistry and specific inhibitors of $\mathrm{CH}_{4}$, $\mathrm{NH}_{4}{ }^{+}$and $\mathrm{CO}$ oxidation by methanotrophs and nitrifiers, Microbiol. Rev. 53, 68-84, 1989. 
Berson, O., and M.E. Lidstrom, Study of copper accumulation by the type I methanotroph Methylomicrobium albus BG8G, Env. Sci. Technol. 30, 802-809, 1996.

Blumenberg, M., R. Seifert and W. Michaelis, Aerobic methanotrophy in the oxic-anoxic transition zone of the Black Sea water column, Organic Geochem. 38, 84-91, 2007.

Brewer, P.G., and E.T. Peltzer, Limits to marine life, Science 324, 347-348, 2009.

Brewer, P.G., C. Paull, E.T. Peltzer, W. Ussler, G. Rehder and G. Friederich, Measurements of the fate of gas hydrates during transit through the ocean water column, Geophys. Res. Lett. 29, GL014727, 2002.

Broecker, W.S., and T.H. Peng, Tracers in the Sea, Eldigio Press, Lamont Doherty Geological Observatory, 1982.

Christian, J.R., and T.R. Anderson, Modeling DOM biogeochemistry, in Biogeochemistry of Marine Dissolved Organic Matter, edited by D.A. Hansell and C.A. Carlson, 717-755, Academic Press, Amsterdam, 2002.

Cicerone, R.J., and R. S. Oremland, Biogeochemical aspects of atmospheric methane, Global Biogeochem. Cycles 2, 299-327, 1988.

Coffin, R.B., M.T. Montgomery and C.L. Osburn, Impact of a hydrate based marine desalination technology on marine microbiota and water quality, Naval Research Laboratory NRL/MR/6110-06-9005, 2006.

Conrad, R., Capacity of aerobic microorganisms to utilize and grow on atmospheric trace gases $\left(\mathrm{H}_{2}, \mathrm{CO}\right.$ and $\left.\mathrm{CH}_{4}\right)$, in Current Perspectives in Microbial Ecology, edited by M.J. King and C.R. Reddy, 461-467, American Society for Microbiology, Washington D.C. 1994. 
Conrad, R., and W. Seiler, Methane and hydrogen in seawater (Atlantic Ocean), Deep Sea Res. 35, 1903-1917, 1988.

Cowen, J.P., X. Wen and B. Popp, Methane in aging hydrothermal plumes, Geochim. Cosmochim. Acta 66, 3563-3571, 2002.

Cranston, R.E., G.D. Ginsburg, V.A. Soloviev, T.D. Lorenson, Gas venting and hydrate deposits in the Okhotsk Sea. Bull. Geol. Soc. Denmark 41, 80-85, 1994.

Damm, E., and G. Budeus, Fate of vent derived methane in seawater above the Hakon Mosby mud volcano (Norwegian Sea), Marine Chem. 82, 1-11, 2003.

Damm, E., A. Mackensen, G. Budeus, E. Faber and C. Hanfland, Pathways of methane in seawater: Plume spreading in an Arctic shelf environment (SW Spitsbergen), Continental Shelf Res. 25, 1453-1472, 2005.

de Angelis, M.A., M.D. Lilley, E.J. Olson and J.A. Baross, Methane oxidation in deep sea hydrothermal plumes of the Endeavour segment of the Juan de Fuca Ridge, Deep Sea Res. 40, 1169-1186, 1993.

Egorov, A.V., K. Crane, P.R. Vogt and A.N. Rozhkov, Gas hydrates that outcrop on the seafloor: Stability models, Geo-Mar. Lett. 19, 68-75, 1999.

Elliott, S., Dependence of DMS global sea-air flux distribution on transfer velocity and concentration field type, J. Geophys. Res. 114, G02001, 2009.

Freeland, H.J., A.S. Bychkov, F. Whitney, C. Taylor, C.S. Wong and G.I. Yurasov, WOCE section P1W in the Sea of Okhotsk 1. Oceanographic data description, J. Geophys. Res. 103, 15613-15623, 1998.

Gent, P.R., and J.C. McWilliams, Isopycnal mixing in ocean circulation models, J. Phys. Oceanogr., 20, 150-155, 1990. 
Gent, P.R., F.O. Bryan, G. Danabasoglu, K. Lindsay, D. Tsumune, M.W. Hecht and S.C. Doney, Ocean chlorofluorocarbon and heat uptake during the twentieth century in CCSM3, J. Climate, 19, 2,366-2,381, 2006.

Gornitz, V., and I. Fung, Potential distribution of methane hydrates in the world's oceans, Global Biogeochem. Cycles, 8, 335-347, 1994.

Graham, D.W., J.A. Chaudhary, R.S. Hanson and R.G. Arnold, Factors affecting competition between type I and II methanotrophs in two organism, continuous flow reactors, Microbial Eco. 25, 1-17, 1993.

Grant, N.J., and M.J. Whiticar, Stable carbon isotopic evidence for methane oxidation in plumes above Hydrate Ridge, Cascadia Oregon Margin, Global Biogeochem. Cycles 16, GB001851, 2002.

Griffiths, R.P., B.A. Caldwell, J.D. Cline, W. A. Broich and R.A. Morita, Field observations of methane concentrations and oxidation rates in the Southeastern Bering Sea, Appl. Environ. Microbiol. 44, 435-446, 1982.

HAAO, Hydrochemical Atlas of the Arctic Ocean, International Arctic Research Center, Fairbanks Alaska, 2001.

Hanson, R.S., and T.E. Hanson, Methanotrophic bacteria, Microbiol. Rev. 439-471, 1996.

Heeschen, K.U., A.M. Trehu, R.W. Collier, E. Suess and G. Rehder, Distribution and height of methane bubble plumes on the Cascadia Margin characterized by acoustic imaging, Geophys. Res. Lett. 30, GL1016974, 2003.

Heggie, D., G. Klinkhammer and D. Cullen, Manganese and copper fluxes from continental margin sediments, Geochim. Cosmochim. Acta 51, 1059-1070, 1987. 
Holloway, G. and 16 others, Water properties and circulation in Arctic Ocean models, J. Geophys. Res. 112, JC003642, 2007.

Hovland, M., A.G. Judd and R.S. Burke, The global flux of methane from shallow submarine sediments, Chemosphere 26, 559-578, 1993.

IPCC, Climate Change 2007: The Physical Basis, Cambridge University Press, 2007.

Judd, A.G., The global importance and context of methane escape from the seabed, GeoMar. Lett. 23, 147-154, 2003.

Kalnay, E., and 21 others, The NCEP/NCAR 40-year reanalysis project, Bull. Am. Met. Soc. 77, 437-471, 1996.

Karl, D.M., L. Beversdorf, K.M. Bjorkman, M.J. Church, A. Martinez and E. F. DeLong, Aerobic production of methane in the sea, Nature Geosci. 1, 473-478, 2008.

Kelley, C.A., and W.H. Jeffrey, Dissolved methane concentration profiles and air-sea fluxes from $41^{\circ} \mathrm{S}$ to $27^{\circ} \mathrm{N}$. Global Biogeochem. Cycles 16, GB001809, 2002.

King, G., Ecological aspects of methane oxidation, a key determinant of global methane dynamics, Adv. Microbial Ecol. 12, 431-468, 1992.

Kvenvolden, K.A., and A. Grantz, Gas hydrates in the Arctic Ocean region, in The Arctic Ocean Region, Geology of North America, 539-549, Geological Society of America, Boulder Colorado, 1990.

Kvenvolden, K.A., T.D. Lorenson and W.S. Reeburgh, Attention turns to naturally occurring methane seepage. EOS 82, 457, 2001.

Lamarque, J.F. Estimating the potential for methane clathrate instability in the 1\% CO2 IPCC AR-4 simulations, Geophys. Res. Lett. 35, GL035291, 2008. 
Lammers, S., E. Suess and M. Hovland, A large methane plume east of Bear Island (Barents Sea) -Implications for the marine methane cycle, Geologische Rundschau 84, 59-65, 1995a.

Lammers, S., E. Suess, M.N. Mansurov and V.V. Anikiev, Variations of atmospheric methane supply from the Sea of Okhotsk induced by the seasonal ice cover, Global Biogeochem. Cycles 9, 351-358, 1995b.

Large, W.G., and S.G. Yeager, Diurnal to Decadal Global Forcing for Ocean and Sea-Ice Models: The Data Sets and Flux Climatologies, NCAR Technical Note 460+STR, National Center for Atmospheric Research, Boulder CO, 2004.

Large, W.G., J.C. McWilliams and S.C. Doney, Oceanic vertical mixing: Review and a model with a nonlocal boundary layer parameterization, Rev. Geophys. 32, 363-403, 1994.

LaRock, P.A., J.H. Hyun and B.W. Bennison, Bacterioplankton growth and production at the Louisiana hydrocarbon seeps, Geo-Mar. Lett. 14, 104-109, 1994.

Leifer, I., and R.K. Patro, The bubble mechanism for methane transport from the shallow seabed to the surface: A review and sensitivity study. Continental Shelf Res. 22, 2409-2428, 2002.

Leifer, I., J.F. Clark and R.F. Chen, Modifications of the local environment by natural marine hydrocarbon seeps, Geophys. Res. Lett. 27, 3711-3714, 2000.

Leifer, I., H. Jeuthe, S.H. Gjosund, and V. Johanson, Engineered and Natural Marine Seep, Bubble-Driven Buoyancy Flows. J. Phys. Oceanogr. 39, 3071-3090, 2009. Longhurst, A., Ecological Geography of the Sea, Academic Press, San Diego, 1998. 
Mau, S., D.L. Valentine, J.F. Clark, J. Reed, R. Camilli, and L. Washburn, Dissolved methane distributions and air-sea flux in the plume of a massive seep field, Coal Oil Point, California, Geophys. Res. Lett. 34, GL031344, 2007.

Milkov, A.V., Global estimates of hydrate-bound gas in marine sediments: How much is really out there?, Earth Sci. Rev. 66, 183-197, 2004.

Moore, J.K., S. Doney and K. Lindsay, Upper ocean ecosystem dynamics and iron cycling in a global 3D model, Global Biogeochem. Cycles, 18, GB4028, 2004.

Nihous, G.C., and S.M. Masutani, A model of methane concentration profiles in the open ocean, J. Mar. Res. 64, 629-650, 2006.

Oremland, R.S., Methanogenic activity in plankton samples and fish intestines: A mechanism for in situ methanogenesis in oceanic surface waters. Limnol. Oceanogr. 24, 11336-1141, 1979.

Peng, T.H., T. Takahashi and W.S. Broecker, Seasonal variability of carbon dioxide, nutrients and oxygen in the northern North Atlantic surface water: Observations and a model, Tellus 39B, 439-458, 1987.

Reagan, M.T., and G.J. Moridis, Dynamic Response of oceanic hydrate deposits to ocean temperature change, J. Geophys. Res. 113, JC004938, 2008.

Reeburgh, W.S., Oceanic methane biogeochemistry, Chem. Rev. 107, 486-513, 2007.

Rehder, G., R.S. Keir, and E. Suess, Methane in the northern Atlantic controlled by microbial oxidation and atmospheric history, Geophys. Res. Lett. 26, 587-590, 1999.

Rehder, G., R.W. Collier, K. Heeschen, P.M. Kosro, J. Barth and E. Suess, Enhanced marine $\mathrm{CH}_{4}$ emissions to the atmosphere off Oregon caused by coastal upwelling, Global Biogeochem. Cycles 16, GB001391, 2002a. 
Rehder, G., P.W. Brewer, E.T. Peltzer and G. Friederich, Enhanced lifetime of methane bubble streams within the deep ocean, Geophys. Res. Lett. 29, GL013966, 2002b.

Sabine, C.L., R.M. Key, A. Kozyr, R.A. Feely, R. Wanninkhof, F.J. Millero, T.H. Peng, J.L. Bullister and K. Lee, Global Ocean Data Analysis Project: Results and Data. The Carbon Dioxide Information Analysis Center, Oak Ridge National Laboratory, Tennessee, 2005.

Schlosser, P., J.H. Swift, D. Lewis and S.L. Pfirman, The role of large-scale Arctic Ocean circulation in the transport of contaminants, Deep Sea Res. II 42, 1341-1367, 1995.

Schubert, C.J. and 11 others, Aerobic and anaerobic methanotrophs in the Black Sea water column, Environ. Microbiol. 8, 1844-1856, 2006.

Scranton, M.I., and P.G. Brewer, Consumption of dissolved methane in the deep ocean, Limnol. Oceanogr. 23, 1207-1213, 1978.

Smith, R.D., and J.C. McWilliams, Anisotropic horizontal viscosity for ocean models, Ocean Modelling 5, 129-156, 2003.

Steele, M., R. Morley and W. Ermold, PHC: A global ocean hydrography with a high quality Arctic Ocean, J. Climate 14, 2079-2087, 2001.

Stumm, W., and J.J. Morgan, Aquatic Chemistry, John Wiley and Sons, New York, 1981.

Suess, E. and 10 others, Fluid venting in the eastern Aleutian subduction zone, J. Geophys. Res. 103, 2597-2614, 1998.

Tilbrook, B.S., and D.M. Karl, Methane sources, distributions and sinks from California coastal waters to the oligotrophic North Pacific gyre, Marine Chem. 49, 51-64, 1995. 
Valentine, D.L., D.C. Blanton, W.S. Reeburgh, and M. Kastner, Water column methane oxidation adjacent to an area of active hydrate dissociation, Eel River Basin, Geochim. Cosmochim. Acta 65, 2633-2640, 2001.

Walsh, J.J., D.A. Dieterle, W. Maslowski and T.E. Whitledge, Decadal shifts in biophysical forcing of Arctic marine food webs: Numerical consequences, J. Geophys. Res. 109, JC001945, 2004.

Wanninkhof, R., Relationship between wind speed and gas exchange over the ocean, J. Geophys. Res., 97, 7373-7382, 1992.

Ward, B.B., and K.A. Kilpatrick, Methane oxidation associated with mid-depth maxima in the Southern California Bight, Continental Shelf Res. 13, 1111-1122, 1993.

Warneck, P., Chemistry of the Natural Atmosphere, Academic Press, San Diego, 2000.

Watanabe, S., N. Higashitini, N. Tsurushima and S. Tsunogai, Methane in the western North Pacific, J. Oceanogr 51, 39-60, 1995.

Welhan, J.A., and H. Craig, Methane and hydrogen in East Pacific Rise hydrothermal fluids. Geophys. Res. Lett. 6, 829-831, 1979.

Westbrook, G., and 18 others, Escape of methane gas from the seabed along the West Spitsbergen continental margin, Geophys. Res. Lett. 36, GL039191, 2009.

Wiesenburg, D.A., and N.L. Guinasso, Equilibrium solubilities of methane, carbon monoxide and hydrogen in water and sea water, J. Chem. Eng. Data 24, 356-360, 1979.

WOA, World Ocean Atlas, National Ocean Data Center, National Oceanic and Atmospheric Administration, 2005. 
Corresponding author: Scott Elliott, the Climate Ocean Sea Ice Modeling team, Los Alamos National Laboratory, Los Alamos NM 87545, USA (sme@lanl.gov) 
Table 1. Determinations of the methane removal time from seawater at selected open marine and coastal sites. Methods range from injection of radio-labeled excess to comparison with tracers of opportunity to transport competition. Values are rounded from multiple reported measurements in most cases. The data are arranged in order of increasing methane level so that the pattern of time scale decrease is apparent.

\begin{tabular}{|l|l|l|l|l|}
\hline Location & Depth & Concentration & Lifetime & Reference \\
\hline East Pacific Rise & Abyssal & $1 \mathrm{nM}$ & $10,000 \mathrm{~d}$ & Welhan and Craig 1979 \\
\hline Cascadia Endeavour & $2000 \mathrm{~m}$ & $1 \mathrm{nM}$ & $1000 \mathrm{~d}$ & de Angelis et al. 1993 \\
\hline Icelandic North Atlantic & $\mathrm{NADW}$ & $1 \mathrm{nM}$ & $10,000 \mathrm{~d}$ & Rehder et al. 1999 \\
\hline Northern California & $0-300 \mathrm{~m}$ & $10 \mathrm{nM}$ & $1000-10,000 \mathrm{~d}$ & Valentine et al. 2001 \\
\hline Aleutians, Bering slope & $300 \mathrm{~m}$ & $10-30 \mathrm{nM}$ & $30 \mathrm{~d}$ & Griffiths et al. 1982 \\
\hline California Bight & $1000 \mathrm{~m}$ & $30 \mathrm{nM}$ & $300 \mathrm{~d}$ & Ward \& Kilpatrick 1993 \\
\hline Northern California & $300-500 \mathrm{~m}$ & $300 \mathrm{nM}$ & $300 \mathrm{~d}$ & Valentine et al. 2001 \\
\hline Cascadia Endeavour & $2000 \mathrm{~m}$ & $300 \mathrm{nM}$ & $10 \mathrm{~d}$ & de Angelis et al. 1993 \\
\hline Spitsbergen & $300-1000 \mathrm{~m}$ & $300 \mathrm{nM}$ & $10 \mathrm{~d}$ & Damm et al. 2005 \\
\hline
\end{tabular}


Table 2. Checks on background model results based on the sparse central ocean measurement set. Excluding saturation ratios, data are arranged in order of increasing concentration within each category.

\begin{tabular}{|c|c|c|c|c|}
\hline \multicolumn{2}{|l|}{ Model } & \multicolumn{3}{|l|}{ Measurement } \\
\hline Environment & Concentration & Location & Concentration & Reference \\
\hline \multirow[t]{2}{*}{ Abyss } & $<1 \mathrm{nM}$ & North Atlantic & $<1 \mathrm{nM}$ & Scranton \& Brewer 1978 \\
\hline & & Sources Endeavour $^{1}$ & $1 \mathrm{nM}$ & de Angelis et al. 1993 \\
\hline \multirow[t]{3}{*}{ Thermocline } & $1-10 \mathrm{nM}$ & North Pacific & $1-10 \mathrm{nM}$ & Watanabe et al. 1995 \\
\hline & & Central Atlantic & $1-10 \mathrm{nM}$ & Conrad \& Seiler 1988 \\
\hline & & Galapagos & $10 \mathrm{nM}$ & Kelley \& Jeffrey 2002 \\
\hline \multirow[t]{5}{*}{ Midlatitude slope } & $10-30 \mathrm{nM}$ & Oregon Upwell $^{2}$ & $10-30 \mathrm{nM}$ & Rehder et al. 2002a \\
\hline & & California Bight & $20 \mathrm{nM}$ & Ward \& Kilpatrick 1993 \\
\hline & & Plume Endeavour & $300-500 \mathrm{nM}$ & de Angelis et al. 1993 \\
\hline & & Hydrate Ridge & 300-3000 nM & Grant \& Whiticar 2002 \\
\hline & & Plume Endeavour & $1000 \mathrm{nM}$ & Cowen et al. 2002 \\
\hline \multirow[t]{3}{*}{ Arctic Slope } & $30-100 \mathrm{nM}$ & Gulf of Alaska & $3-10 \mathrm{nM}$ & Suess et al. 1998 \\
\hline & & Bear Island & $30-100 \mathrm{nM}$ & Lammers et al. 1995a \\
\hline & & Spitsbergen & $300 \mathrm{nM}$ & Damm et al. 2005 \\
\hline \multirow[t]{6}{*}{ Miscellaneous $^{3}$} & $0.1-100 \mathrm{nM}$ & abyssal & $<1 \mathrm{nM}$ & Scranton \& Brewer 1978 \\
\hline & & Henry's Law & $2-4 \mathrm{nM}$ & Bates et al. 1996 \\
\hline & & Santa Barbara $^{4}$ & $30-100 \mathrm{nM}$ & Mau et al. 2007 \\
\hline & & $\begin{array}{l}\text { Santa Barbara } \\
\text { shore }^{4}\end{array}$ & $1 \mu \mathrm{M}$ & Mau et al. 2007 \\
\hline & & Equatorial Upwell & $1.1-1.2\left(\mathrm{SR}^{5}\right)$ & Bates et al. 1996 \\
\hline & & & $1.3-2.0\left(\mathrm{SR}^{5}\right)$ & Kelley \& Jeffrey 2002 \\
\hline
\end{tabular}

${ }^{1}$ Here the word "source" signifies incoming water masses

${ }^{2}$ Continental side of the well studied Hydrate Ridge system

${ }^{3}$ Full ranges for model and data

${ }^{4}$ Shallow seeps give kilometer scale plumes at $0.1-1 \mu \mathrm{M}$, coastal eddies then dissipate ${ }^{5}$ Concentration as Saturation Ratio relative to the atmosphere 
Figure 1. Arctic view of bathymetry, overlaid with a 300 meter isobath and stars at locations of the 8 clathrate injection sites.

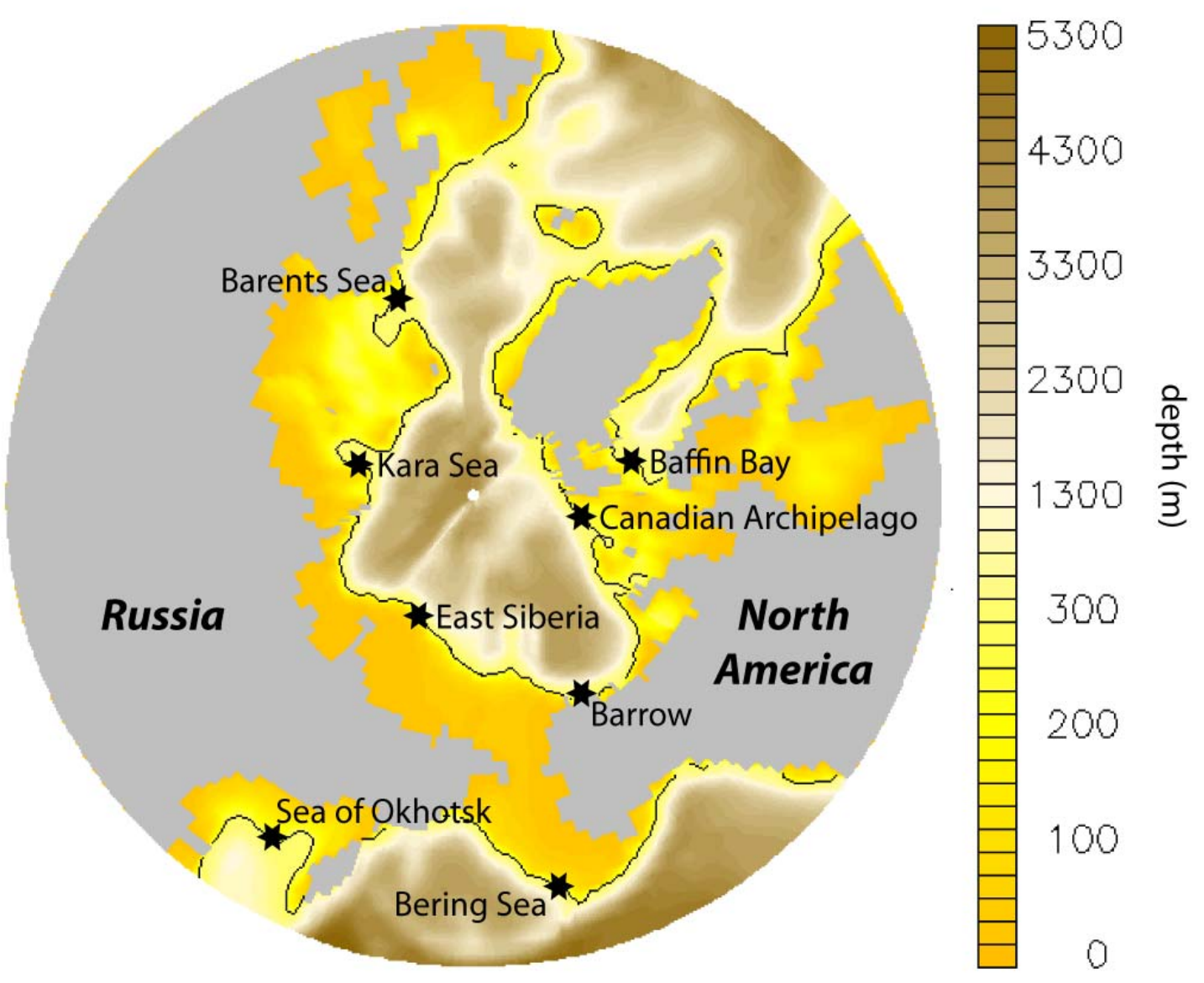


Figure 2. a) Methane distribution at the sea surface for January of the fortieth background year (nM). Color bar interval is 0.1 for concentrations between 0 and 4 , then expands to 0.5 between values of 4 and 12. b) Surface methane saturation ratio relative to the lower atmosphere, for the same run. Color bar interval is 0.01 for values between 0.9 and 1.1, otherwise it is 0.1. c) Background methane distribution at 150 meters depth $(\mathrm{nM})$ overlaid with dissolved oxygen contour lines $(\mu \mathrm{M})$. Color bar interval is 0.25 for methane concentrations between 0 and 10, then expands to 2.0 between values of 10 and 34. The $\mathrm{O}_{2}$ contour interval is 50 .
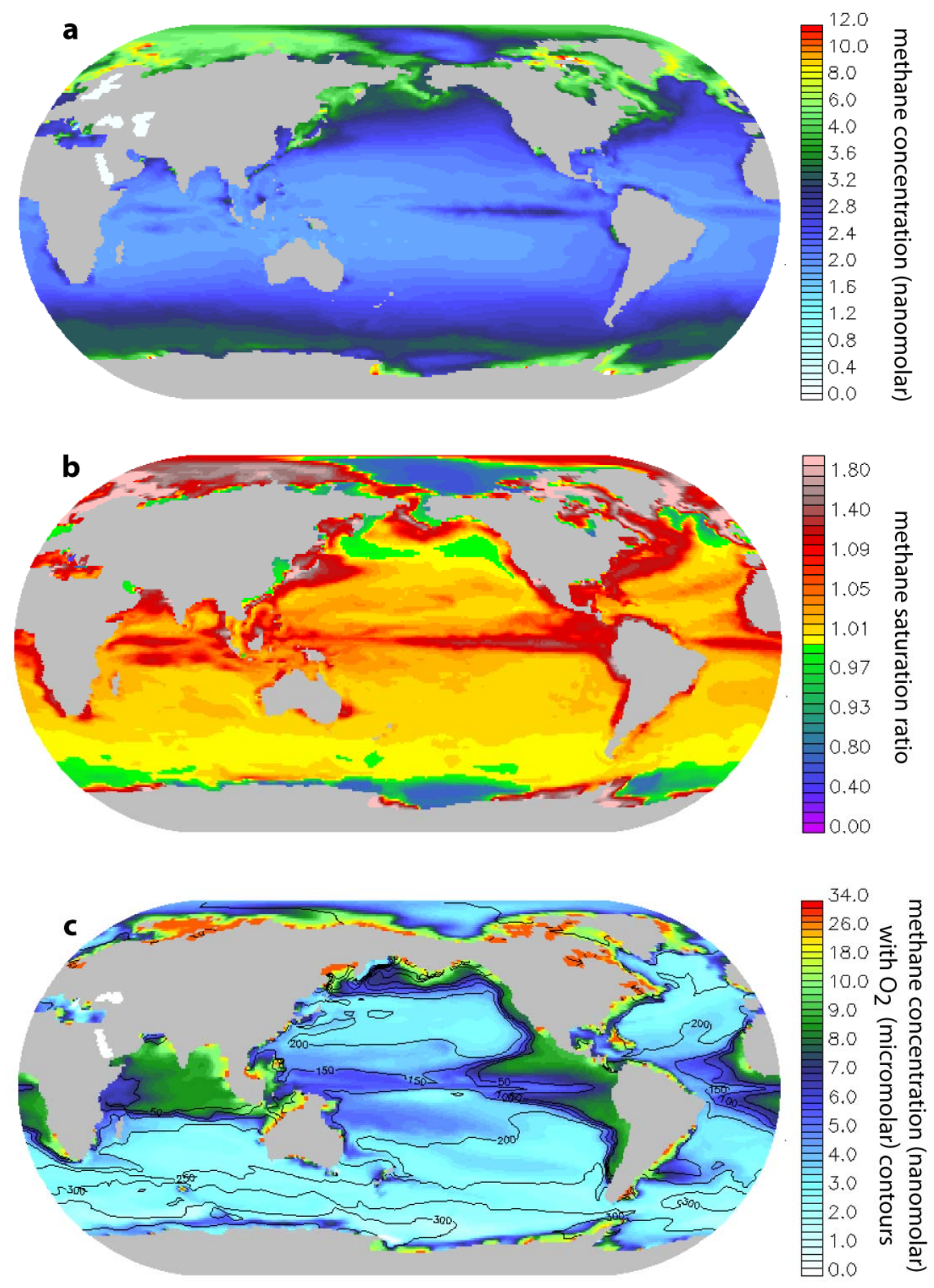
Figure 3. a) Vertical integral of methane concentration (millimole $/ \mathrm{m}^{2}$ ) from January of clathrate year 30. Color bar interval is 0.5 for values between 0 and 20, then expands to 20 between values of 20 and 240. b) Depth profiles of methane concentration $(\mu \mathrm{M})$ averaged over $10^{\circ} \times 10^{\circ}$ boxes surrounding each injection site, for the same run.

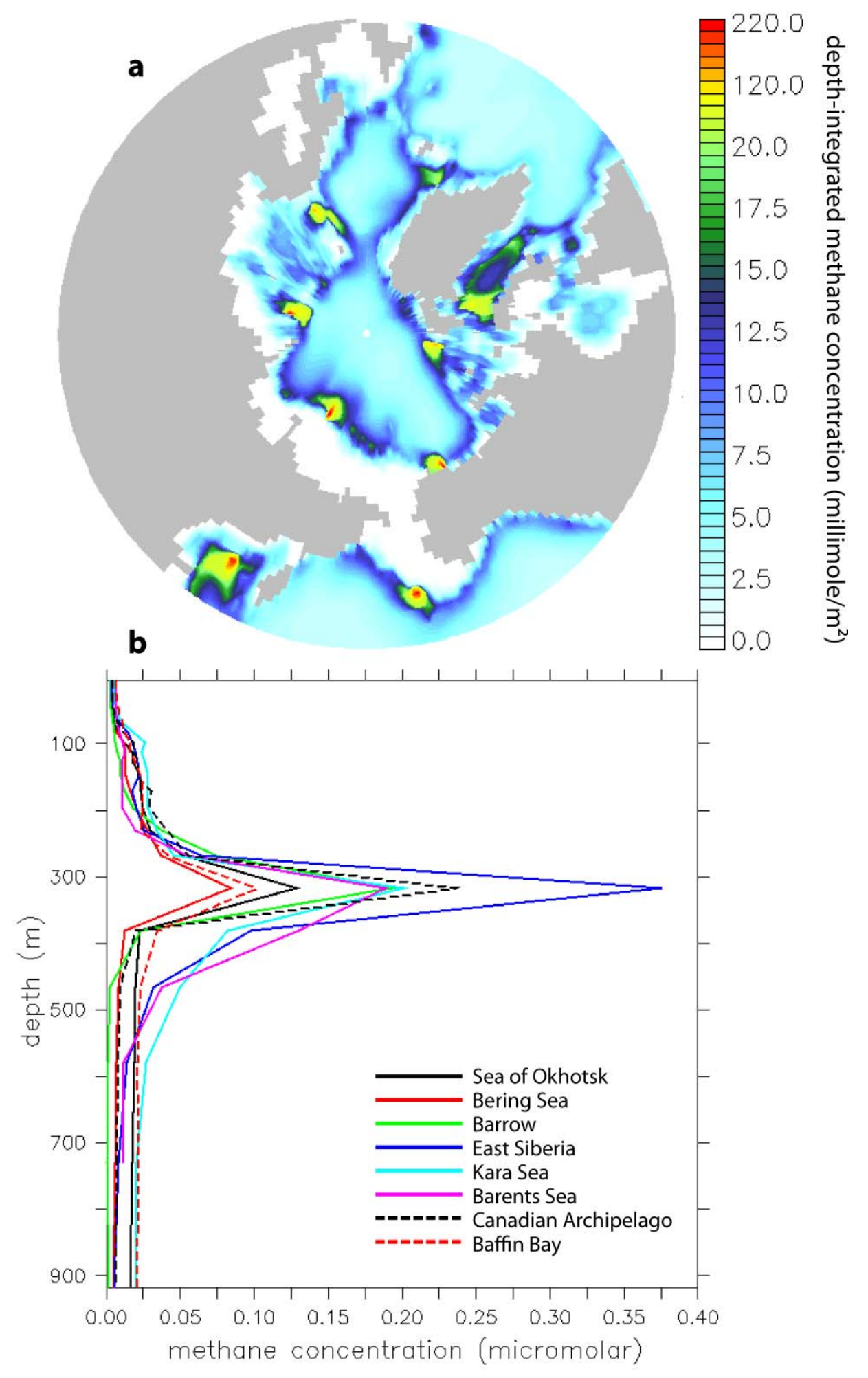


Figure 4. a) Dissolved oxygen concentration at 300 meters depth from January of clathrate year $30(\mu \mathrm{M})$. Regions of severe hypoxia are indicated by white and purple shades. b) Change in $\mathrm{pH}$ relative to the initial state, 300 meters for the same run. Color bar interval is 0.01 for values between -0.17 and -0.05 , then contracts to .001 between values of -0.05 and 0 .
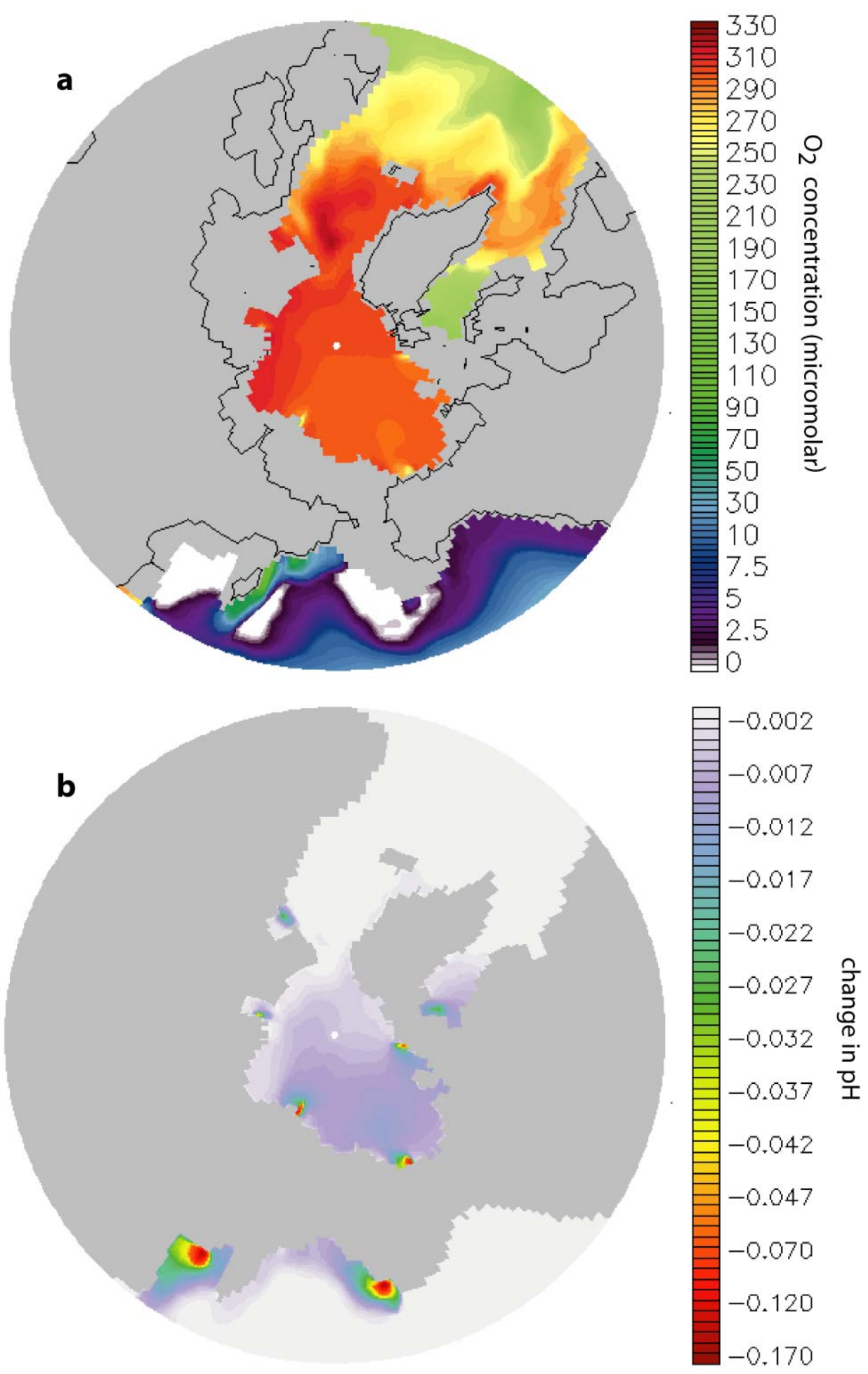
Figure 5. Vertical integral of the methane concentration from January of clathrate year $30\left(\right.$ millimole $\left./ \mathrm{m}^{2}\right)$, in a simulation with oxygen limitation. Color bar interval is 1.0 for values between 0 and 20, expands to 20 between values of 20 and 200, then expands further to 200 between values of 200 and 6000 .

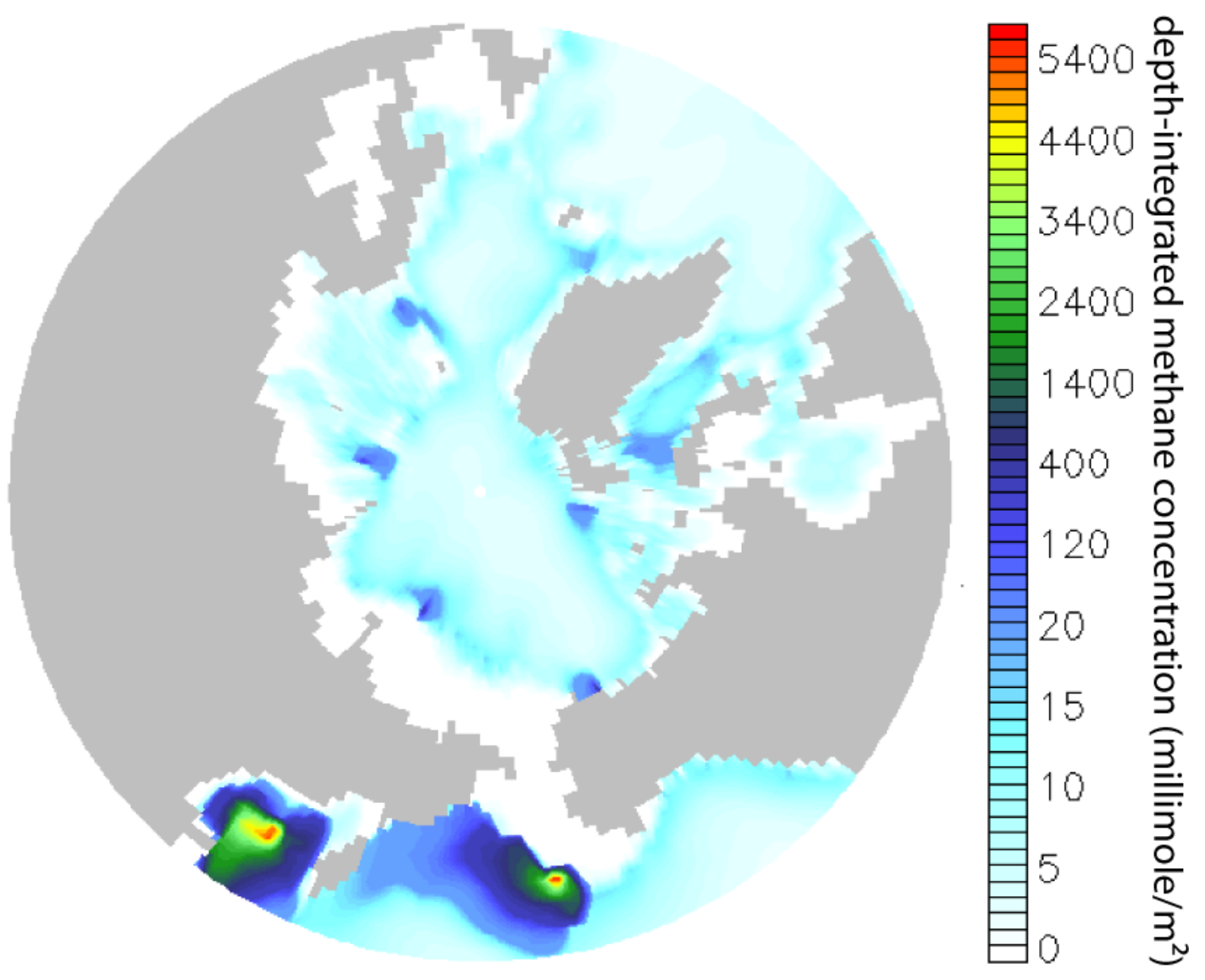


Figure 6. a) Vertical integral of the concentration (millimole $/ \mathrm{m}^{2}$ ) from January of clathrate year 30 in a simulation with inert methane. Color bar is the same as in Figure 5. b) Vertical profile of the methane concentration averaged over the entire polar region north of $50^{\circ} \mathrm{N}$ for the same run $(\mu \mathrm{M})$.

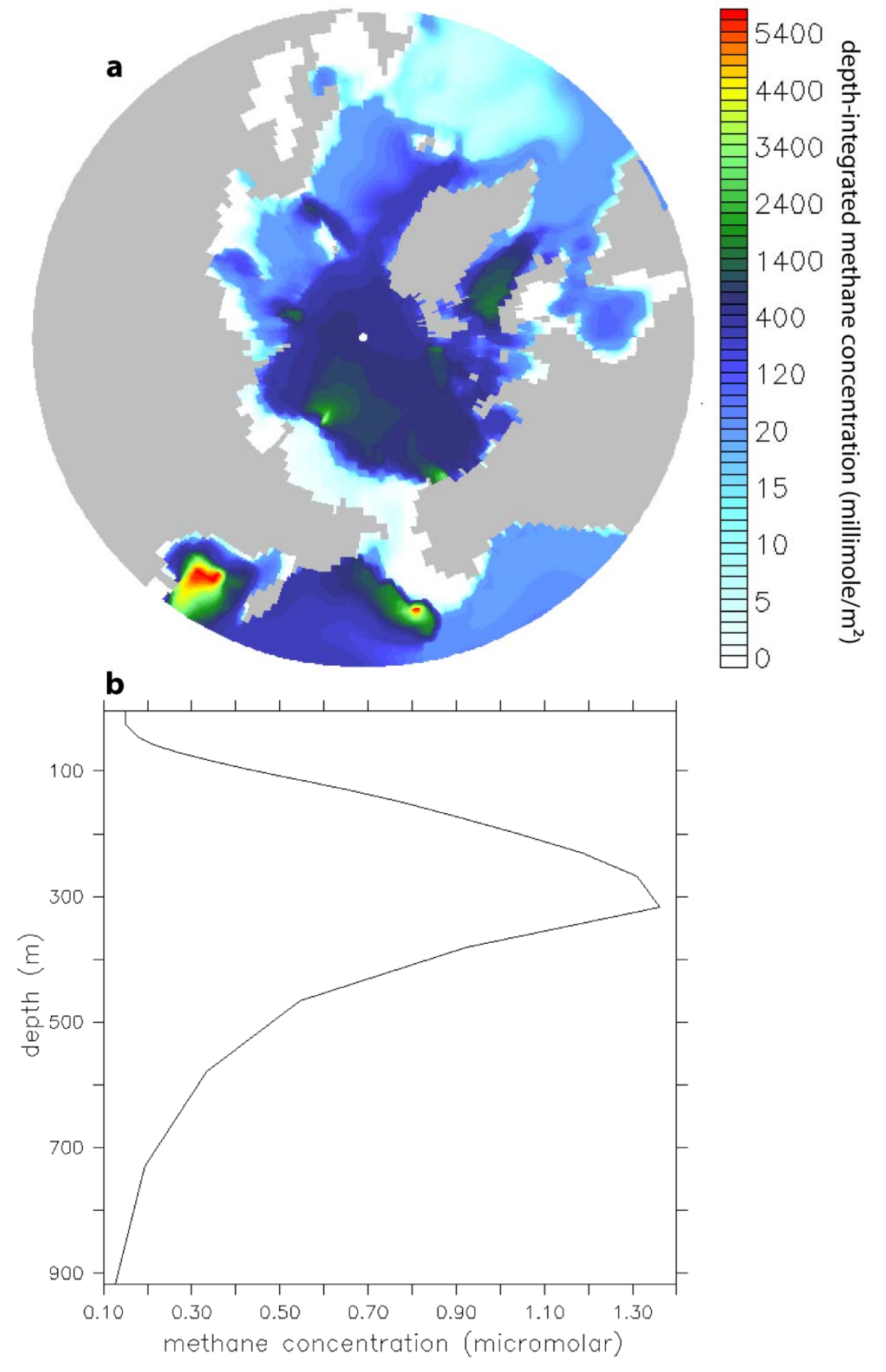


Figure 7. Total monthly averaged transfer of inert methane through the oceanatmosphere interface north of $50^{\circ}$, relative to the amount added at 8 injection sites (thin curve). The thick curve represents a 12 month boxcar smoothing that eliminates the seasonal cycle.

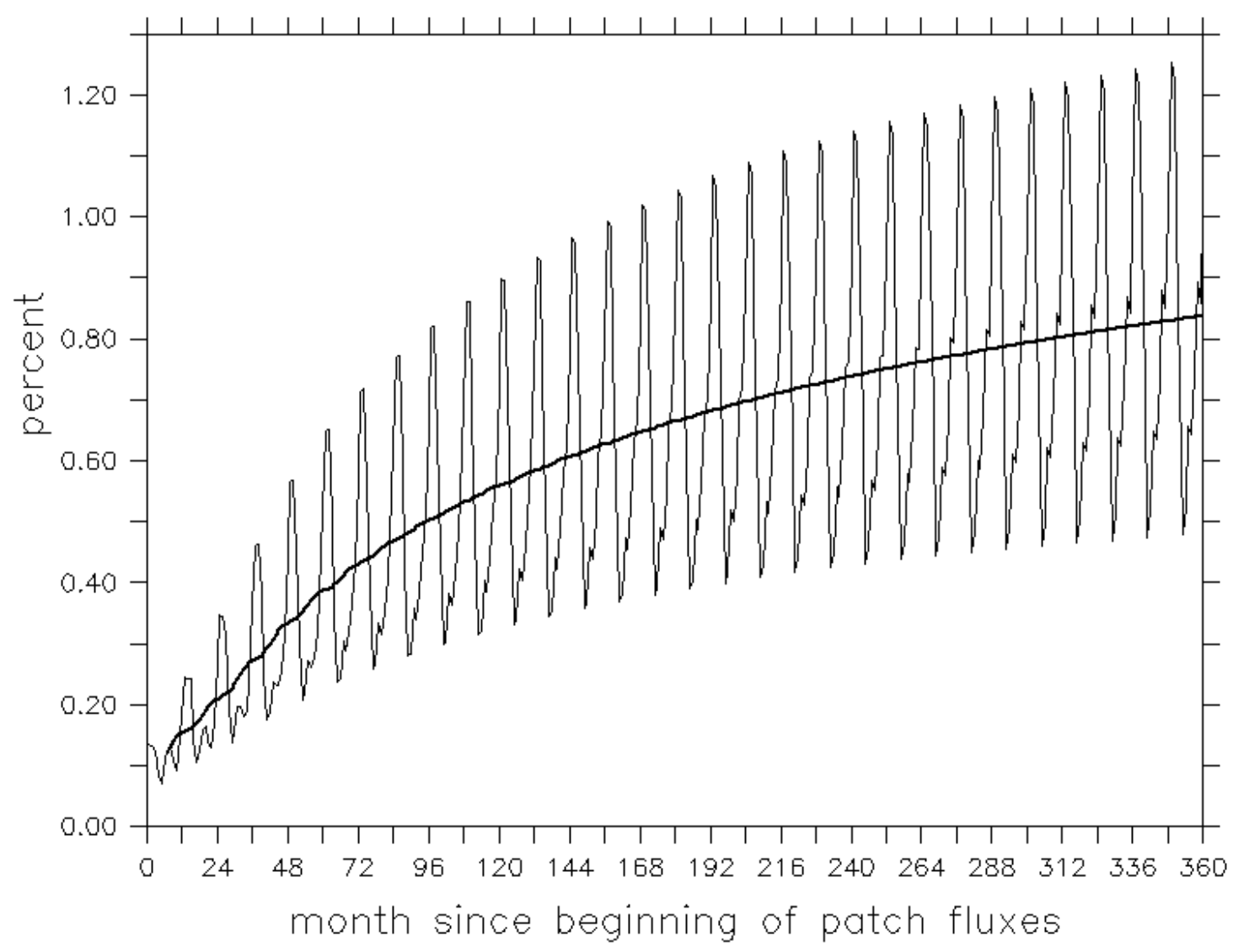

